\title{
Risk factors for subclinical and clinical ketosis and association with production parameters in dairy cows in the Netherlands
}

\author{
T. Vanholder, ${ }^{* 1}$ J. Papen,† R. Bemers, $†$ G. Vertenten, ${ }^{*}$ and A. C. B. Berge \\ *Elanco Animal Health, Antwerp 2018, Belgium \\ †De Graafschap Veterinarians, Vorden $7251 \mathrm{MX}$, the Netherlands \\ †Department of Reproduction, Obstetrics and Herd Health, Faculty of Veterinary Medicine, Ghent University, Merelbeke 9820, Belgium
}

\begin{abstract}
Ketosis is associated with many transition cow diseases and the subclinical form has been found to be a common condition in high-producing dairy cows. The objectives of this field study in the Netherlands were (1) to determine risk factors for subclinical ketosis [SCK; $1.2-2.9 \mathrm{mmol}$ of $\beta$-hydroxybutyrate (BHBA)/L of serum] and clinical ketosis (CK: $\geq 3.0 \mathrm{mmol}$ of $\mathrm{BHBA} / \mathrm{L}$ of serum) at 7 to $14 \mathrm{~d}$ in milk and (2) to assess the association of SCK and CK with production parameters at the first dairy herd improvement (DHI) testing. Twenty-three dairies were enrolled by a local veterinary practice from 2009 to 2010, and 1,715 cows were screened for ketosis by measuring serum BHBA concentrations at 7 to $14 \mathrm{~d}$ in milk. Overall, $47.2 \%$ of cows had SCK and $11.6 \%$ had CK. Mixed generalized logit models with a random effect of herd were used to evaluate cow level factors associated with SCK and CK. The associations of SCK and CK with milk production parameters were tested using mixed linear models with a random effect of herd. Cows at a moderate (3.25-3.75) or fat $(\geq 4)$ body condition score before calving were more likely to develop SCK and CK than thin (body condition score $\leq 3.0$ ) cows. The risk for developing SCK was higher in parity 2 and older cows compared with heifers, whereas for CK only, parity $\geq 3$ cows had a higher risk. The quarter of the year in which a cow calved was associated with the risk for SCK and CK. For SCK quarter 1 (January-March) and quarter 2 (April-June), and for CK quarter 1, quarter 2, and quarter 3 (July-September) all increased the risk of development of the condition compared with quarter 4 (October-December). An increased yield of colostrum at first milking was associated with increasing risk for SCK and CK. Prolonged previous lactation length and dry period length were both associated with increased odds for SCK and CK. Subclinical ketosis and CK were
\end{abstract}

Received May 14, 2014.

Accepted October 29, 2014

${ }^{1}$ Corresponding author: Vanholder_tom@elanco.com associated with a higher milk yield, a higher milk fat percentage, and a lower milk protein percentage at first DHI test day. Overall the study reinforces previous findings that the major risk factors for both SCK and CK are increasing parity, overconditioning of animals prepartum, season of calving, and dry period length. In addition, previous lactation length and liters of colostrum have been identified as additional risk factors for the development of ketosis.

Key words: dairy cow, ketosis, risk factor

\section{INTRODUCTION}

Ketosis, either present at a subclinical or clinical level, is a common metabolic condition in the modern high-producing dairy cow and has been associated with many fresh cow diseases. The transition period, defined as 3 wk before until 3 wk after calving (Grummer, 1995), is a critical period for a dairy cow. During the transition period, the cow needs to adjust her metabolism to partition nutrients and energy to support milk synthesis, a process referred to as homeorrhesis (Bauman and Currie, 1980). The imbalance between energy requirements for milk production and energy intake through feed causes a negative energy balance, which results in metabolic conditions such as hyperketonemia (Herdt, 2000). Around 30 to $50 \%$ of dairy cows develop metabolic or infectious diseases around the moment of calving (LeBlanc, 2010) and relationships between hyperketonemia or ketosis and fresh cow diseases have been described (Berge and Vertenten, 2014). Cows with subclinical ketosis, defined as blood BHBA concentrations above 1 to $1.4 \mathrm{mmol} / \mathrm{L}$, are at an increased risk of developing a displaced abomasum, metritis, clinical ketosis, and lameness (LeBlanc et al., 2005; Duffield et al., 2009; Seifi et al., 2011; Suthar et al., 2013; Berge and Vertenten, 2014). In addition, ketosis reduces milk yield and reproductive performance and increases the risk for premature culling in affected cows (Koller et al., 2003; Walsh et al., 2007; Duffield et al., 2009; Ospina et al., 2010; Seifi et al., 2011; McArt et al., 2012). 
Several factors have been identified as risk factors for the development of ketosis. Among these are a high BCS and lower transition period DMI (Gillund et al., 2001; Hayirli et al., 2002; Goldhawk et al., 2009). Increased parity, dry period length, and transition cow feed management have also been associated with an increased ketosis risk (Gustafsson et al., 1995; Duffield et al., 1997; Vickers et al., 2013; Berge and Vertenten, 2014). The ability to predict the risk of ketosis in cows is important to target the most appropriate preventive measures. The objectives of this study were to determine risk factors for fresh cow ketosis at 7 to 14 DIM and to assess the effects of ketosis on milk production parameters at first DHI test day.

\section{MATERIALS AND METHODS}

Twenty-three dairy farms that belonged to the client base of De Graafschap Veterinarians were selected based on willingness of the farmer to participate. All farms were situated within a radius of $20 \mathrm{~km}$ around the practice (Vorden) in the east of the Netherlands. Upon enrollment in August 2009, farms were visited by one of the veterinarians and general farm data (herd size, breed, production level, average age of herd), dry cow, and transition cow management practices were recorded in a template document. In all participating dairy farms cows were housed in free-stall barns, with either zero-grazing or pasture access during the grazing season. Upon weekly visits, cows and heifers with a known expected calving date were identified and individual animal information (cow ID, parity, last calving date, date of dry off, expected calving date) was recorded. Cows were scored for BCS on a 5-point scale with 0.25-unit increments (Edmondson et al., 1989) by 1 of 2 veterinarians between 3 and 1 wk before the expected calving date. Farmers were instructed to register on a template document the actual date of calving, any incident of dystocia, calving ease (no assistance or assistance required), twins, stillbirth (birth of a dead at term calf or death within $1 \mathrm{~h}$ postcalving), retained placenta, milk fever, as well as any treatments administered around calving. Retained placenta was defined as failure of placental expulsion within $12 \mathrm{~h}$ after calving (Laven and Peters, 1996), and diagnosis of milk fever was based on clinical signs (muscular weakness, cold extremities, recumbency, response to intravenous calcium administration, or a combination of these) as described by Berge and Vertenten (2014). Upon first milking, the quantity of colostrum was measured and recorded by pouring the obtained volume of total first milking in a graded 10-L bucket. In the second week after calving (7-14 DIM), a blood sample for BHBA measurement was collected by one of the veterinarians from the coccygeal vein in blood serum collection tubes (BD Vacutainer Serum Tube, BD, Breda, the Netherlands) and allowed to clot. Blood samples were transported to the veterinary practice and serum was collected by centrifugation. Serum samples were stored at $-196^{\circ} \mathrm{C}$ in a cryostat until analysis. Serum BHBA concentration $(\mathrm{mmol} / \mathrm{L})$ was measured using a handheld meter (Precision Xceed, Abbott Laboratories, Abbott Park, IL) at room temperature (Iwersen et al., 2009; McArt et al., 2013). Per farm, milk production data of the first test-day for each cow were collected through an online database of the DHI company (https://www.pir-dap. nl/, CRV, Arnhem, the Netherlands).

Date of calving was categorized into yearly quarters (Q): January-March (Q1), April-June (Q2), JulySeptember (Q3), and October-December (Q4). The quarters of the year were evaluated against temperature and humidity data obtained from the Royal Dutch Meteorological Institute for the region. The meteorological data indicated that division of the year in quarters was in line with observed regional changes in temperature and humidity.

\section{Statistical Analysis}

The data were entered into a spreadsheet (Microsoft Excel 2007, Microsoft Corp., Redmond, WA) and statistically analyzed using SAS 9.4 statistical software. Nonparametric testing and stratified analysis were initially performed, and the variability in predictive factors for inclusion into the statistical models was evaluated. The distributions for the continuous variables were assessed using univariate statistics and plots. Categorical variables of continuous variables were created where appropriate, and as previously described (LeBlanc et al., 2005; McArt et al., 2013). A serum BHBA concentration threshold of $<1.2 \mathrm{mmol} / \mathrm{L}$ was defined as no ketosis (NK), thresholds of $\geq 1.2$ and $<3.0 \mathrm{mmol} / \mathrm{L}$ were defined as subclinical ketosis (SCK), and clinical ketosis $(\mathbf{C K})$ was defined as BHBA concentrations $\geq 3.0 \mathrm{mmol} / \mathrm{L}$ (Oetzel, 2004; McArt et al., 2013). Cows were categorized according to parity $(1,2$, and $\geq 3)$ and BCS (thin $\leq 3$; moderate 3.25-3.75; fat $\geq 4$; Chapinal et al., 2011). Cows eligible for inclusion in the final data set must have had a calving date, parity, and a BCS recorded. For all analyses, statistical significance was set at $P \leq 0.05$.

Generalized logit mixed models were used with the dependent variable being ketosis category: NK, SCK, and CK. The multivariate multinomial logistic regression compared the odds of a cow having SCK or CK compared with NK for various risk factors. The models included a random effect of herd to control for clustering of cows within farm. The first model included 
Table 1. Variables evaluated in generalized estimation equation logit mixed models for association with ketosis status in fresh cows in a field study of 23 dairies in the Netherlands

\begin{tabular}{|c|c|c|}
\hline Variable & $\begin{array}{l}\text { Type of } \\
\text { variable }\end{array}$ & Dependent variable \\
\hline Cow level factors & No. of cows & \\
\hline Lactation length $^{1}$ & Continuous & Previous lactation length in days \\
\hline Quarter of year & Categorical & Calving quarters of year \\
\hline Dry period length ${ }^{1}$ & Continuous & Length of dry period in days \\
\hline Calving interval $^{1}$ & Continuous & Calving interval \\
\hline Parity & Categorical & Parity 1 , parity 2 , or parity $\geq 3$ \\
\hline $\mathrm{BCS}$ & Categorical & Thin $\leq 3 ;$ moderate $3.25-3 . \overline{5} ;$ fat $\geq 4$ \\
\hline Colostrum & Continuous & Liters of colostrum at first milking \\
\hline
\end{tabular}

${ }^{1}$ Variables only evaluated in parity $2+$ model.

both heifers and all higher parity cows. The second model contained parity 2 and higher parity cows to include previous lactation length, calving interval, and dry-period length. Factors were tested in the model if at least $5 \%$ of cows had the presence of the factor per ketosis category. The variables were tested for inclusion using a manual backward selection procedure $(P$-value for retention $\leq 0.05)$. The factors tested for inclusion in models 1 and 2 are described in Table 1. Milk fever was excluded as a risk factor in the analysis since recording was not consistent, and preventive use of IV calcium administration was a common practice in older cows, which may have influenced actual milk fever prevalence. Interactions between variables were tested and retained in the model if $P$-value for retention $\leq 0.05$. Correlations between independent variables were evaluated using a limit of $\mathrm{r}=0.6(P \leq 0.05)$ for a correlation coefficient indicating highly correlated variables, where the most biologically relevant would be chosen.

Relationships between ketosis categories (NK, SCK, $\mathrm{CK}$ ) and the DHI milk test results were tested through a series of mixed models with the DHI test parameters as outcome variables and BHBA category as predictive variable. Parity and days in milk were included as covariates if they were significantly associated with the dependent variable or were confounding the outcome variable (a change in any remaining parameter estimate greater than 15\%). The models included a random ef- fect of farm. The natural log was taken of the somatic cell counts to normalize the data.

\section{RESULTS}

\section{Descriptive Statistics}

Herd size varied from 40 to 148 cows with on average 84 cows present. The overall breed was HolsteinFriesian with Red Holstein also present on 5 farms. The average production across herds for the previous year was $9,023 \mathrm{~kg}$ of milk (herd range from 7,428 to $11,299 \mathrm{~kg}$ ), $4.4 \%$ fat (range 4.17 to $4.68 \%$ ), and $3.5 \%$ protein (range 3.38 to $3.71 \%$ ). Overall $47.2 \%$ of cows were classified as having subclinical ketosis and $11.6 \%$ of cows had clinical ketosis. The distribution of SCK and CK across parity group, BCS category and season is described in Table 2. Information on precalving and calving events and procedures according to ketosis category are described in Table 3. Average colostrum yield and first DHI test-day parameters stratified on ketosis status are presented in Table 4.

\section{Risk Factors for SCK and CK}

The generalized logit mixed model including all parity cows identified cow parity category, BCS category, season, and the quantity of first colostrum produced as

Table 2. Distribution of ketosis status, parity group, BCS group, and season in fresh cows in a field study of 23 dairies in the Netherlands

\begin{tabular}{|c|c|c|c|c|c|c|c|c|c|c|c|}
\hline \multirow[b]{2}{*}{ Item } & \multirow{2}{*}{$\begin{array}{l}\text { No. of } \\
\text { cows }\end{array}$} & \multicolumn{3}{|c|}{ Parity group } & \multicolumn{3}{|c|}{ BCS group } & \multicolumn{4}{|c|}{ Season (quarter of year) ${ }^{1}$} \\
\hline & & 1 & 2 & $3+$ & Thin & Moderate & Fat & 1 & 2 & 3 & 4 \\
\hline \multicolumn{12}{|c|}{ Ketosis status (\%) } \\
\hline None & 707 & 54 & 43 & 34 & 53 & 41 & 27 & 36 & 34 & 45 & 48 \\
\hline Subclinical & 809 & 36 & 49 & 52 & 43 & 47 & 54 & 54 & 47 & 40 & 46 \\
\hline Clinical & 199 & 10 & 8 & 14 & 4 & 12 & 19 & 9 & 18 & 15 & 6 \\
\hline No. of cows & 1,715 & 427 & 464 & 824 & 369 & 1,043 & 303 & 448 & 376 & 370 & 521 \\
\hline
\end{tabular}

${ }^{1} 1=$ January to March; $2=$ April to June; 3 = July to September; and $4=$ October to December. 
Table 3. Precalving data and calving events and procedures in fresh cows in a field study of ketosis in cows in 23 dairies in the Netherlands

\begin{tabular}{|c|c|c|c|c|}
\hline \multirow[b]{2}{*}{ Precalving data } & \multirow{2}{*}{$\begin{array}{c}\text { No. of } \\
\text { cows }\end{array}$} & \multicolumn{3}{|c|}{ Ketosis status } \\
\hline & & None & SCK & CK \\
\hline Dry period days & 1,077 & 51.8 & 56.4 & 64.6 \\
\hline Previous lactation days & 1,072 & 341.3 & 347.6 & 361.6 \\
\hline Calving interval days & 1,280 & 394.6 & 406.8 & 427.0 \\
\hline \multicolumn{5}{|l|}{ Events and procedures } \\
\hline Retained placenta & 1,542 & $13 \%$ & $11 \%$ & $18 \%$ \\
\hline Assisted calving & 1,664 & $39 \%$ & $38 \%$ & $38 \%$ \\
\hline Twins & 1,715 & $9 \%$ & $7 \%$ & $11 \%$ \\
\hline Dead calf & 1,705 & $3 \%$ & $2 \%$ & $4 \%$ \\
\hline C-section/surgery & 1,699 & $2 \%$ & $1 \%$ & $2 \%$ \\
\hline
\end{tabular}

factors associated with SCK and CK in dairy cows at 7 to $14 \mathrm{~d}$ in milk. Overall, increasing parity category was associated with a higher risk of developing SCK and CK. Parity 2 cows were more likely to develop SCK than parity 1 cows [odds ratio $(\mathbf{O R})=2.1, P<0.01$ ], whereas for CK no difference could be detected between parity 1 and 2 cows (Table 5 ). In parity $\geq 3$ cows, the odds for developing SCK or CK were, respectively, 2.8 and 2.2 compared with heifers $(P<0.01$, Table 5$)$. The BCS category showed a positive association with both SCK and CK. Cows that were classified as moderate body condition were 1.5 times and 3.6 times more likely to experience SCK and CK, respectively, compared with thin cows $(P<0.01$, Table 5$)$. Fat cows $(\mathrm{BCS} \geq 4)$ had 2.7 higher odds of developing SCK and 8.7 higher odds to be diagnosed with $\mathrm{CK}$ than thin cows $(P<$ 0.01 , Table 5). Season of calving showed a clear association with ketosis. When calving in the first and second quarter of the year cows were more likely to develop both SCK (Q1: OR $=1.8, P<0.01 ; \mathrm{Q} 2: \mathrm{OR}=1.4$, $P=0.02$, Table 5) and CK (Q1: $\mathrm{OR}=2.1, P<0.01$; $\mathrm{Q} 2: \mathrm{OR}=4.3, P<0.01$, Table 5$)$ compared with cows calving in Q4. In addition, cows calving in Q3 were 2.9 times more likely to develop CK than those calving in Q4 $(P<0.01$, Table 5$)$. Risk increased for SCK and CK with increasing colostrum production at first milking. For every 1-L increase in colostrum production (as compared with mean production), the odds of SCK and CK increased by a factor $1.1(P<0.01)$ and $1.2(P<$ 0.01 ), respectively (Table 5 ). None of the calving events and procedures was associated with ketosis.

The model excluding heifers identified similar overall trends for season, parity, BCS, and colostrum production, although liters of colostrum was not significantly associated with SCK ( $P=0.07$; Table 6$)$. No differences in odds for SCK could be observed between parity 2 cows and $\geq 3$ cows, whereas for CK the odds were 1.9 times higher in the latter compared with the previous category $(P=0.02$, Table 6$)$. Increasing length of the dry period increased the odds of SCK $(P=0.01)$ and CK $(P<0.01)$, as did prolonged previous lactation length for CK $(P=0.02$, Table 6$)$.

\section{Association of Ketosis with First DHI Test-Day Parameters}

A higher milk yield at first DHI testing was positively associated with SCK and CK (Table 7). Milk yield of SCK cows $(35.7 \pm 0.7)$ was $1.2 \mathrm{~L}$ higher than that of NK cows $(34.5 \pm 0.7 \mathrm{~kg} ; P<0.01)$, whereas cows with CK $(36.2 \pm 0.7 \mathrm{~kg})$ produced on average $1.7 \mathrm{~L}$ more than NK cows $(P<0.01)$. The milk yield ratio (actual liters/expected liters) tended to be higher in the SCK and CK cows compared with the NK cows $(P=0.05)$.

Table 4. Milk production parameters at first DHI test day, with exception of colostrum, in fresh cows in a study of ketosis in dairies in the Netherlands

\begin{tabular}{|c|c|c|c|c|}
\hline \multirow[b]{2}{*}{ Parameter } & \multirow{2}{*}{$\begin{array}{c}\text { No. of } \\
\text { cows }\end{array}$} & \multicolumn{3}{|c|}{ Ketosis status } \\
\hline & & None & SCK & CK \\
\hline Colostrum (L) & 1,572 & 4.7 & 5.6 & 7.2 \\
\hline Actual yield (L)/expected yield (L) & 1,149 & 0.99 & 1.02 & 1.00 \\
\hline Milk (L) & 1,149 & 34.6 & 37.9 & 36.8 \\
\hline $\mathrm{SCC} \times 1,000$ & 1,149 & 212.9 & 131.5 & 186.8 \\
\hline Protein $\%$ & 1,149 & 3.4 & 3.3 & 3.2 \\
\hline Fat $\%$ & 1,149 & 4.2 & 4.3 & 4.6 \\
\hline
\end{tabular}


Table 5. Generalized logit mixed model of factors associated with subclinical and clinical ketosis in cows in a field study of 23 dairies in the Netherlands

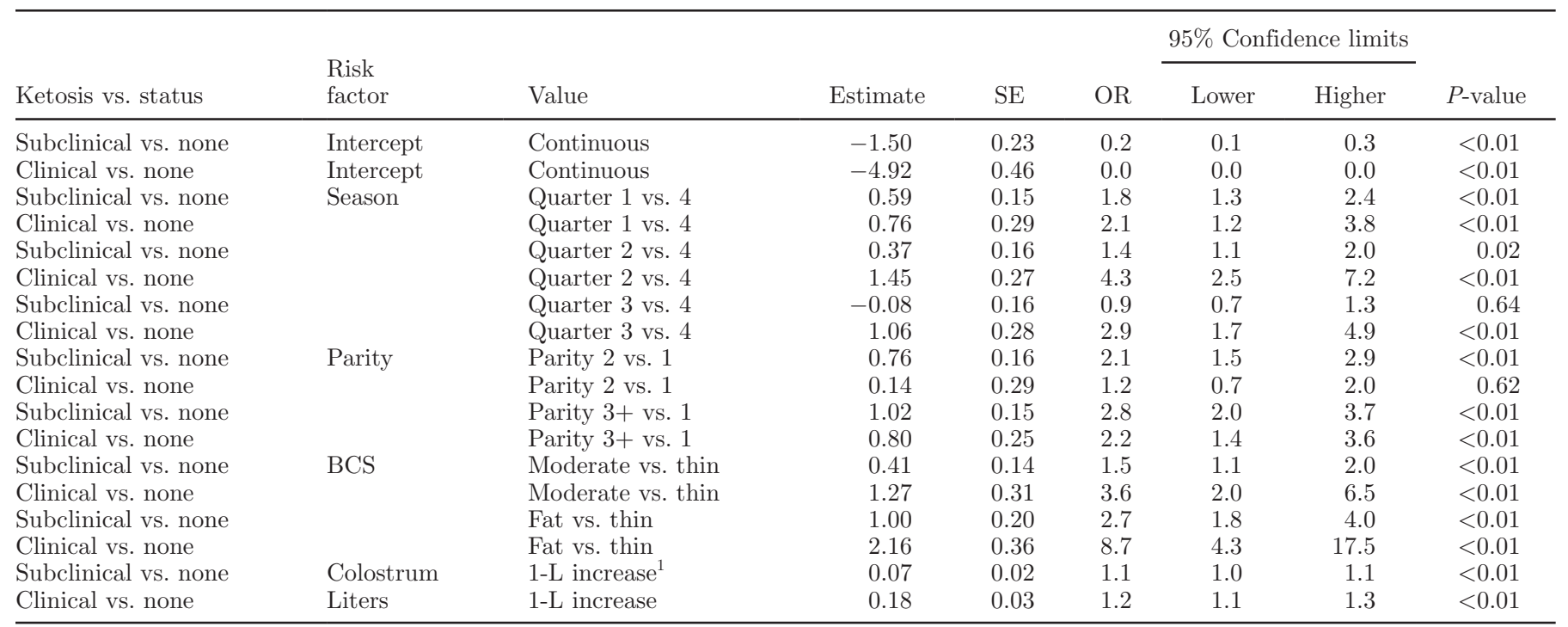

${ }^{1}$ Effects assessed as $1 \mathrm{~L}$ offset from the mean of $5.43 \mathrm{~L}$.

The protein $\%$ of milk was lower in the SCK cows $(3.29$ $\pm 0.02 \% P<0.01)$ and the CK cows $(3.17 \pm 0.03 \% ; P$ $<0.01)$ compared with the NK cows $(3.39 \pm 0.02 \%)$. The fat $\%$ of milk was higher in both SCK cows $(4.32 \pm$ $0.04 \%, P=0.04)$ and the CK cows $(4.53 \pm 0.07 \%, P<$ $0.01)$ compared with the NK cows $(4.22 \pm 0.05 \%)$. Ketosis status was not associated with somatic cell count $(P=0.8$ for SCK vs. NK; $P=0.51$ for CK vs. NK).

\section{DISCUSSION}

This study indicates that both SCK and CK are highly prevalent in postpartum cows in the Netherlands. Observed prevalences in this study are similar to or higher than earlier reported data from studies performed in the United States and Europe (McArt et al., 2012; Suthar et al., 2013; Berge and Vertenten,

Table 6. Generalized logit mixed model of factors associated with subclinical and clinical ketosis in parity 2 and higher parity cows in a field study of 23 dairies in the Netherlands

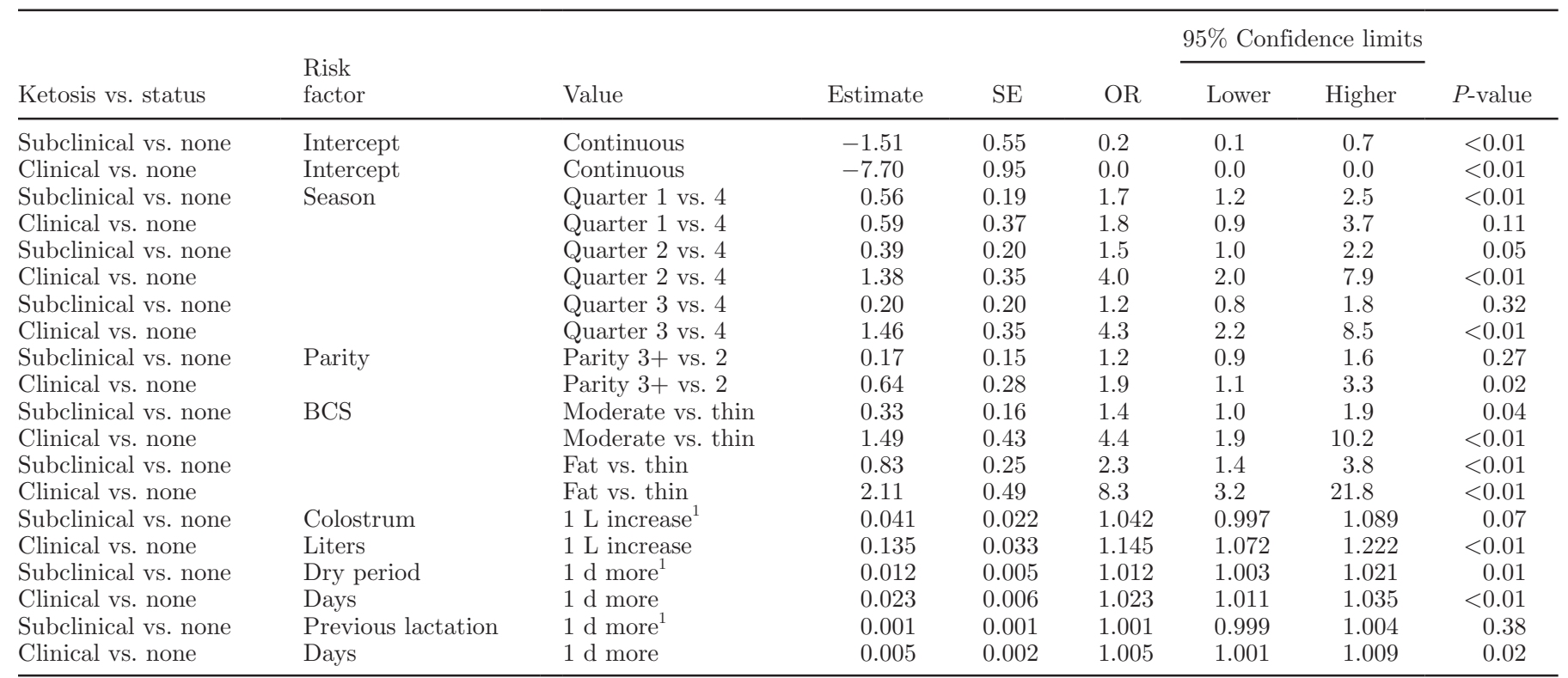

${ }^{1}$ Effects assessed as 1 unit offset from the mean. 
Table 7. A series of mixed models of the effect of subclinical and clinical ketosis on DHI milk production parameters in fresh cows in a field study of 23 dairies in the Netherlands

\begin{tabular}{|c|c|c|c|c|c|c|c|}
\hline Item & $\begin{array}{l}\text { Predictive } \\
\text { factor }\end{array}$ & Value & LSM & $\mathrm{SE}$ & \multicolumn{2}{|c|}{$95 \% \mathrm{CI}$} & $P$-value \\
\hline \multirow{7}{*}{ Milk yield (L) } & \multirow{2}{*}{ Ketosis } & Subclinical & 35.7 & 0.7 & 34.3 & 37.0 & $<0.01$ \\
\hline & & Clinical & 36.2 & 0.7 & 34.7 & 37.6 & $<0.01$ \\
\hline & Parity & 1 & 29.7 & 0.7 & 28.3 & 31.1 & Reference \\
\hline & \multirow[t]{4}{*}{ Season } & Quarter 1 & 36.6 & 0.7 & 35.3 & 38.0 & $<0.01$ \\
\hline & & Quarter 2 & 35.8 & 0.7 & 34.4 & 37.1 & $<0.01$ \\
\hline & & Quarter 3 & 35.0 & 0.7 & 33.6 & 36.4 & 0.20 \\
\hline & & Quarter 4 & 34.4 & 0.8 & 32.9 & 35.9 & Reference \\
\hline Milk yield ratio & \multirow[t]{3}{*}{ Ketosis } & None & 0.99 & 0.01 & 0.97 & 1.01 & Reference \\
\hline \multirow[t]{2}{*}{ Actual/expected } & & Subclinical & 1.02 & 0.01 & 1.01 & 1.04 & 0.05 \\
\hline & & Clinical & 1.01 & 0.01 & 0.98 & 1.04 & 0.05 \\
\hline \multirow{4}{*}{ Milk protein $\%$} & Ketosis & Clinical & 3.17 & 0.03 & 3.11 & 3.23 & $<0.01$ \\
\hline & \multirow[t]{3}{*}{ Parity } & 1 & 3.24 & 0.02 & 3.19 & 3.29 & Reference \\
\hline & & 2 & 3.33 & 0.02 & 3.28 & 3.38 & $<0.01$ \\
\hline & & $3+$ & 3.28 & 0.02 & 3.24 & 3.32 & 0.14 \\
\hline \multirow[t]{6}{*}{ Milk fat $\%$} & \multirow[t]{3}{*}{ Ketosis } & None & 4.22 & 0.05 & 4.13 & 4.31 & Reference \\
\hline & & Subclinical & 4.32 & 0.04 & 4.23 & 4.41 & 0.04 \\
\hline & & Clinical & 4.53 & 0.07 & 4.40 & 4.66 & $<0.01$ \\
\hline & \multirow[t]{3}{*}{ Parity } & 1 & 4.30 & 0.05 & 4.19 & 4.41 & Reference \\
\hline & & 2 & 4.33 & 0.05 & 4.23 & 4.44 & 0.56 \\
\hline & & $3+$ & 4.43 & 0.04 & 4.35 & 4.52 & 0.01 \\
\hline \multicolumn{8}{|l|}{ Model } \\
\hline \multirow[t]{3}{*}{ Ln SCC } & \multirow[t]{3}{*}{ Ketosis } & None & 10.9 & 0.1 & 10.7 & 11.0 & Reference \\
\hline & & Subclinical & 10.8 & 0.1 & 10.7 & 11.0 & 0.80 \\
\hline & & Clinical & 10.9 & 0.1 & 10.7 & 11.2 & 0.51 \\
\hline
\end{tabular}

2014). Regional and country differences in dairy cow husbandry play an important role in ketosis prevalence in general, as indicated by the country differences reported in the European studies. Differences in study design and methodology may also account for differences in prevalence estimates. Peak prevalence of SCK occurs within the first week after calving (McArt et al., 2012), and we measured BHBA concentrations in serum in wk 2 . However, in our study, $48 \%$ of cows were parity $\geq 3$ cows, compared with $31 \%$ reported in the McArt et al. (2012) paper. Because increasing parity is a risk factor for both SCK (Santschi et al., 2011; Suthar et al., 2013; Berge and Vertenten, 2014) and CK (Detilleux et al., 1994), this most likely has influenced ketosis prevalence in our study. In addition, determination of BHBA concentrations in serum with a more recently modified version of the Precision Xceed, has been reported to give a slight overestimation of actual BHBA concentrations (Iwersen et al., 2013).
Our outcome of overconditioned cows being more at risk for both SCK and CK in the transition period is in line with numerous previous articles (Duffield et al., 1998; Gillund et al., 2001; McArt et al., 2013). A high BCS precalving reduces DMI (Hayirli et al., 2002), and cows that develop SCK postcalving ingest less dry matter before calving (Goldhawk et al., 2009). As a consequence, the metabolic imbalance in these animals will have already commenced before parturition, causing excessive mobilization of fat reserves and lipidosis in the liver: stages preceding hyperketonemia postcalving (Herdt, 2000). Our data also show that even moderately conditioned cows had an increased risk of developing ketosis compared with thin cows. Although $\mathrm{BCS}$ is a reliable predictor of overall lipid storage in the nonlactating cow (Wright and Russel, 1984), subcutaneous and visceral fat storages do not always correlate that well in individual animals (Hostens et al., 2012). A recent paper by Drackley et al. (2014) showed that 
excess energy intake in nonlactating cows over an 8-wk period results in an increase in visceral adipose tissue but not necessarily in an increase in BCS. As such, cows with an apparently moderate body condition may actually possess a high visceral fat storage, increasing the risks for metabolic problems similar to cows with a high BCS. This field study confirms findings of previous studies of an increased risk of SCK and CK with increasing parity (Santschi et al., 2011; Suthar et al., 2013; Berge and Vertenten, 2014). The increased risk for higher parity cows to develop a more severe metabolic imbalance during the transition period is valuable knowledge when attempting to target prevention measures for ketosis.

The seasonal ketosis trends of our study agree with recent European studies that also observed the highest risk for ketosis in calvings in the second quarter of the year (Suthar et al., 2013; Berge and Vertenten, 2014). Cows calving during the first quarter had higher BHBA concentrations compared with the 4th quarter, which confirms the results from older studies that the winter season remains a risk for hyperketonemia (Andersson and Emanuelson, 1985; Grohn et al., 1989). During the first half of the year, Dutch farmers will tend to feed a different grass silage or silage from another cut of grass, often of lesser quality compared with the one used in the last month of the year. Recent data on effect of season on CK are scarce, but Suthar et al. (2013) found a lower risk of CK for cows calving in August and September compared with May, which is in accordance with our findings. In addition, SCK is a risk factor for CK, and as such it is logical that risk factors for SCK such as season are also risk factors for CK.

This study confirms previous findings that increasing dry period length may increase the risk of SCK (Santschi et al., 2011). Although we also found an association of dry period length with CK, Santschi et al. (2011) did not. This may be attributed to differences in definition and methodology because they measured ketosis in milk using test strips and defined severe ketosis as BHBA concentrations in milk $\geq 200 \mu \mathrm{mol} / \mathrm{L}$. Sensitivity of milk test strips to detect hyperketonemic cows is only around 54\% at this threshold (Oetzel, 2004), which may have caused misclassification of cows. A longer lactation length was associated with an increased risk of CK, but not SCK. This may be due to an increased risk of overconditioning. Due to the average farm size in the Netherlands, production groups are rarely formed and a single ration is used for all lactation stages. As a consequence, cows can easily be overfed during the last third of their lactation and enter the dry period overconditioned, which in turn will increase the risk for CK. Although in our models BCS was incorporated as a variable, overfeeding cows can result in increased visceral fat storages without affecting BCS, as demonstrated in nonlactating cows (Drackley et al., 2014). Additionally, fatty acid profiles differ between type of fat storage, which may result in different metabolic effects upon mobilization (Hostens et al., 2012). Additionally, ketosis is associated with production (Duffield et al., 2009) and Dutch farmers often respect a longer voluntary waiting period for higher yielding animals, leading to delayed first insemination and conception. This would then result in a longer lactation period in those higher yielding animals.

To our knowledge, this study is the first to describe an association between increasing colostrum production and the risk of SCK and CK in both heifers and cows. The energy requirements for the onset of milk production increase in parallel with the quantity of colostrum and milk produced and thereby increased risks of negative energy balance (Harrison et al., 1990). Practical experience has indicated that feeding an excessive energy dense ration during the dry period results in high colostrum yields and decreased DMI. Avoiding overfeeding of dry cows in terms of energy and feeding a low energy-high fiber ration to dry cows may be helpful in reducing metabolic stress after calving (Dann et al., 2006; Janovick et al., 2011). Feeding a high roughage and high fiber ration has been shown to reduce SCK incidence in dairy cows after calving (Vickers et al., 2013). Colostrum yield does however not seem to be related to later lactation performance (Kessler et al., 2014). We hypothesize that cows with a high colostrum yield are not necessarily more productive than cows with a lower yield, which may be due to a metabolic imbalance. Unfortunately, this study did not include data on dry cow ration composition and energy and protein content throughout the study period, which could lead to some further insights into the metabolic imbalances of transition cows.

We found no association between ketosis and RP as previously described (Berge and Vertenten, 2014). The prevalence of RP in this study was $12.5 \%$ compared with $4.4 \%$, and this is higher than the prevalence detected in Dutch herds in the cited study (A. C. Berge, personal communication). The definition of retained placenta was set at $12 \mathrm{~h}$ after birth, and this very narrow time span might have caused misclassifications for cows that were calving when not directly observed such as at night times. This type of overdiagnosis would bias estimates toward the null.

Calving-associated events (calving ease, stillbirth, and twinning) were not associated with ketosis at 7 to 14 DIM. An association between calving ease and stillbirth with SCK has previously been reported (McArt et al., 2013). However, in that paper the authors indicate the associations may have been confounded by some 
other herd effect because in the final overall model, the 2 parameters were excluded. Additionally, McArt et al. (2013) found that cows producing male calves had an increased risk of SCK between 3 and 16 DIM. Unfortunately, calf sex was not recorded in our study to confirm such an association. Dystocia has been reported to be a risk factor for CK diagnosed in wk 1 of lactation, but not wk 2 (Duffield et al., 2009). Because we did not measure BHBA concentrations in wk 1, we were unable to support this earlier finding.

Cows carrying twins require 50 to $70 \%$ more energy during late gestation (Nishida et al., 1997) and one previous publication found slightly higher odds for ketosis in cows with twins (Markusfeld, 1987). Neither we nor McArt et al. (2013) found an association of twinning with SCK. Recent research suggest that energy balance in twin-carrying animals postcalving may be slightly better compared with cows with single calves, which can be attributed to lower milk yield in the previous group (Silva-del-Rio et al., 2010).

The association of SCK and CK with first DHI testday fat and protein percentage is in line with previous publications (Duffield et al., 1997, 2009). In comparison with these previous papers, we did not observe a negative association between ketosis and actual milk yield at first test day. On the contrary, SCK and CK in our study were associated with a higher yield. In the Duffield et al. (2009) study, effects of ketosis on production were most pronounced in animals experiencing SCK in wk 1 postpartum. Our sampling was only performed in wk 2 postcalving. Milk yield at first DHI test was reduced in cows with SCK in wk 2, but they actually had a higher predicted 305-d yield. In addition, the optimal threshold for an effect of SCK on milk yield in wk 2 was $2 \mathrm{mmol} / \mathrm{L}$, which was above our set threshold of SCK. Earlier publications on the effect of CK on milk yield indicated a temporary negative effect, although overall predicted 305-d yield was higher in affected animals (Detilleux et al., 1994). These results indicate that higher producing cows are at a higher risk for ketosis.

\section{CONCLUSIONS}

A higher BCS, advanced parity and an increasing volume of first colostrum were major risk factors for developing SCK and CK in cows and heifers in the second week postpartum. In addition, calving season is another important risk factor for ketosis, with the second quarter of the year resulting in the highest risk of ketosis, followed by the first quarter. Lengthening the dry period was an additional risk factor for SCK and CK, whereas a longer previous lactation also increased the risk of $\mathrm{CK}$ in the second week postpartum.

\section{ACKNOWLEDGMENTS}

The authors thank all farmers participating in this study for providing the necessary data and their cooperation throughout the study period. We also thank all veterinarians from the veterinary practice De Graafschap (Vorden, the Netherlands) for their cooperation, and our colleague, Michael Steele (Elanco Animal Health EMEA), for English revision of the manuscript.

\section{REFERENCES}

Andersson, L., and U. Emanuelson. 1985. An epidemiological study of hyperketonaemia in Swedish dairy cows: Determinants and the relation to fertility. Prev. Vet. Med. 3:449-462.

Bauman, D. E., and W. B. Currie. 1980. Partitioning of nutrients during pregnancy and lactation: A review of mechanisms involving homeostasis and homeorhesis. J. Dairy Sci. 63:1514-1529.

Berge, A. C., and G. Vertenten. 2014. A field study to determine prevalence, dairy herd management systems and fresh cow clinical conditions associated with ketosis in western European dairy herds. J. Dairy Sci. 97:2145-2154.

Chapinal, N., M. Carson, T. F. Duffield, M. Capel, S. Godden, M. Overton, J. E. P. Santos, and S. J. LeBlanc. 2011. The association of serum metabolites with clinical disease during the transition period. J. Dairy Sci. 94:4897-4903.

Dann, H. M., N. B. Litherland, J. P. Underwood, M. Bionaz, A. D'Angelo, J. W. McFadden, and J. K. Drackley. 2006. Diets during far-off and close-up dry periods affect periparturient metabolism and lactation in multiparous cows. J. Dairy Sci. 89:3563-3577.

Detilleux, J. C., Y. T. Gröhn, and R. L. Quaas. 1994. Effects of clinical ketosis on test day milk yields in Finnish Ayrshire cattle. J. Dairy Sci. $77: 3316-3323$.

Drackley, J. K., R. L. Wallace, D. Graugnard, J. Vasquez, B. F. Richards, and J. J. Loor. 2014. Visceral adipose tissue mass in nonlactating dairy cows fed diets differing in energy density. J. Dairy Sci. 97:3420-3430.

Duffield, T. F., D. F. Kelton, K. E. Leslie, K. D. Lissemore, and J. H. Lumsden. 1997. Use of test day milk fat and milk protein to detect subclinical ketosis in dairy cattle in Ontario. Can. Vet. J. 38:713-718.

Duffield, T. F., K. D. Lissemore, B. W. McBride, and K. E. Leslie. 2009. Impact of hyperketonemia in early lactation dairy cows on health and production. J. Dairy Sci. 92:571-580.

Duffield, T. F., D. Sandals, K. E. Leslie, K. Lissemore, B. W. McBride, J. H. Lumsden, P. Dick, and R. Bagg. 1998. Efficacy of monensin for the prevention of subclinical ketosis in lactating dairy cows. J. Dairy Sci. 81:2866-2873.

Edmondson, A. J., I. J. Lean, L. D. Weaver, T. B. Farver, and G. Webster. 1989. A body condition scoring chart for Holstein cows. J. Dairy Sci. 72:68-78.

Gillund, P., O. Reksen, Y. T. Grohn, and K. Karlberg. 2001. Body condition related to ketosis and reproductive performance in Norwegian dairy cows. J. Dairy Sci. 84:1390-1396.

Goldhawk, C., N. Chapinal, D. M. Veira, D. M. Weary, and M. A. von Keyserlingk. 2009. Prepartum feeding behavior is an early indicator of subclinical ketosis. J. Dairy Sci. 92:4971-4977.

Grohn, Y. T., H. N. Erb, C. E. McCulloch, and H. S. Saloniemi. 1989. Epidemiology of metabolic disorders in dairy cattle: Association among host characteristics, disease, and production. J. Dairy Sci. 72:1876-1885.

Grummer, R. R. 1995. Impact of changes in organic nutrient metabolism on feeding the transition dairy cow. J. Anim. Sci. 73:2820 2833 .

Gustafsson, A. H., L. Andersson, and U. Emanuelson. 1995. Influence of feeding management, concentrate intake and energy intake on the risk of hyperketonemia in Swedish dairy herds. Prev. Vet. Med. 22:237-248. 
Harrison, R. O., S. P. Ford, J. W. Young, A. J. Conley, and A. E. Freeman. 1990. Increased milk production versus reproductive and energy status of high producing dairy cows. J. Dairy Sci. 73:2749-2758.

Hayirli, A., R. R. Grummer, E. V. Nordheim, and P. M. Crump. 2002. Animal and dietary factors affecting feed intake during the prefresh transition period in Holsteins. J. Dairy Sci. 85:3430-3443.

Herdt, T. H. 2000. Ruminant adaptation to negative energy balance. Influences on the etiology of ketosis and fatty liver. Vet. Clin. North Am. Food Anim. Pract. 16:215-230.

Hostens, M., V. Fievez, J. L. Leroy, R. J. Van, B. Vlaeminck, and G. Opsomer. 2012. The fatty acid profile of subcutaneous and abdominal fat in dairy cows with left displacement of the abomasum. J. Dairy Sci. 95:3756-3765.

Iwersen, M., U. Falkenberg, R. Voigtsberger, D. Forderung, and W. Heuwieser. 2009. Evaluation of an electronic cowside test to detect subclinical ketosis in dairy cows. J. Dairy Sci. 92:2618-2624.

Iwersen, M., D. Klein-Jöbstl, M. Pichler, L. Roland, B. Fidlschuster, I. Schwendenwein, and M. Drillich. 2013. Comparison of 2 electronic cowside tests to detect subclinical ketosis in dairy cows and the influence of the temperature and type of blood sample on the test results. J. Dairy Sci. 96:7719-7730.

Janovick, N. A., Y. R. Boisclair, and J. K. Drackley. 2011. Prepartum dietary energy intake affects metabolism and health during the periparturient period in primiparous and multiparous Holstein cows. J. Dairy Sci. 94:1385-1400.

Kessler, E. C., R. M. Bruckmaier, and J. J. Gross. 2014. Milk production during the colostral period is not related to the later lactational performance in dairy cows. J. Dairy Sci. 97:2186-2192. http://dx.doi.org/10.3168/jds.2013-7573.

Koller, A., M. Reist, J. W. Blum, and U. Kupfer. 2003. Time empty and ketone body status in the early postpartum period of dairy cows. Reprod. Domest. Anim. 38:41-49.

Laven, R. A., and A. R. Peters. 1996. Bovine retained placenta: Aetiology, pathogenesis and economic loss. Vet. Rec. 139:465-471.

LeBlanc, S. J. 2010. Monitoring metabolic health of dairy cattle in the transition period. J. Reprod. Dev. 56:S29-S35.

LeBlanc, S. J., K. E. Leslie, and T. F. Duffield. 2005. Metabolic predictors of displaced abomasum in dairy cattle. J. Dairy Sci. 88:159-170.

Markusfeld, O. 1987. Periparturient traits in seven high dairy herds. Incidence rates, association with parity, and interrelationships among traits. J. Dairy Sci. 70:158-166.
McArt, J. A., D. V. Nydam, and G. R. Oetzel. 2012. Epidemiology of subclinical ketosis in early lactation dairy cattle. J. Dairy Sci. 95:5056-5066.

McArt, J. A., D. V. Nydam, and G. R. Oetzel. 2013. Dry period and parturient predictors of early lactation hyperketonemia in dairy cattle. J. Dairy Sci. 96:198-209.

Nishida, T., M. Kurihara, F. Terada, and M. Shibata. 1997. Energy requirements of pregnant Holstein dairy cows carrying single or twin Japanese black fetuses in late pregnancy. Anim. Sci. Technol. 68:572-578.

Oetzel, G. R. 2004. Monitoring and testing dairy herds for metabolic disease. Vet. Clin. North Am. Food Anim. Pract. 20:651-674.

Ospina, P. A., D. V. Nydam, T. Stokol, and T. R. Overton. 2010. Association between the proportion of sampled transition cows with increased nonesterified fatty acids and beta-hydroxybutyrate and disease incidence, pregnancy rate, and milk production at the herd level. J. Dairy Sci. 93:3595-3601.

Santschi, D. E., D. M. Lefebvre, R. I. Cue, C. L. Girard, and D. Pellerin. 2011. Incidence of metabolic disorders and reproductive performance following a short (35-d) or conventional (60-d) dry period management in commercial Holstein herds. J. Dairy Sci. 94:3322-3330.

Seifi, H. A., S. J. LeBlanc, K. E. Leslie, and T. F. Duffield. 2011. Metabolic predictors of post-partum disease and culling risk in dairy cattle. Vet. J. 188:216-220.

Silva-del-Rio, N., P. M. Fricke, and R. R. Grummer. 2010. Effects of twin pregnancy and dry period feeding strategy on milk production, energy balance, and metabolic profiles in dairy cows. J. Anim. Sci. 88:1048-1060.

Suthar, V. S., J. Canelas-Raposo, A. Deniz, and W. Heuwieser. 2013. Prevalence of subclinical ketosis and relationships with postpartum diseases in European dairy cows. J. Dairy Sci. 96:2925-2938.

Vickers, L. A., D. M. Weary, D. M. Veira, and M. A. von Keyserlingk 2013. Feeding a higher forage diet prepartum decreases incidences of subclinical ketosis in transition dairy cows. J. Anim. Sci. 91:886-894.

Walsh, R. B., J. S. Walton, D. F. Kelton, S. J. LeBlanc, K. E. Leslie, and T. F. Duffield. 2007. The effect of subclinical ketosis in early lactation on reproductive performance of postpartum dairy cows. J. Dairy Sci. 90:2788-2796.

Wright, I. A., and A. J. F. Russel. 1984. Partition of fat, body composition and body condition score in mature cows. Anim. Prod. $38: 23-32$. 